\title{
Concerning Dr. Hartwig's Observations of RZ Cygni.
}

In his valuable paper on new variable stars in Astr. Nachr. 3553, Dr. Hartwig mentions several particulars in which my results for $\mathrm{RZ}$ Cygni differ from those which he obtains. The redness of the star would render close agreement improbable, but as some sources of disagreement can be pointed out, this note may not be out of place.

Dr. Hartwig's hypothesis that I have mistaken his comparison star $\triangleright y$ \& for the variable, will not stand, as I recognized its presence at my third observation and since that time have used it almostly constantly as a comparison star. Moreovtr, I measured the co-ordinates from the variable

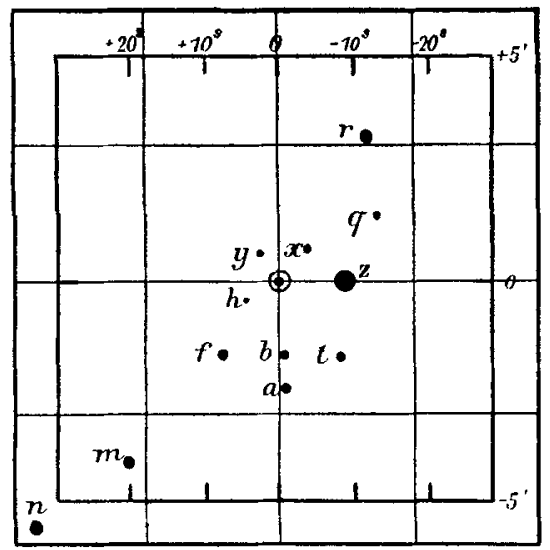

of the stars which I have lettered $h, x, y$, and $z$, with the Clark micrometer attached to the 12 -inch refractor of the Yerkes Observatory, thus assuring myself that no other stars as bright as $14^{\mathrm{m}}$ were so placed that they might be mistaken for the variable. As Dr. Hartwig's chart omits my stars $h$ and $y$, which are essential to the correct identification of the variable at minimum, I append a list of my comparison stars, giving in the successive columns my letter, the coordinates from the variable, the magnitude, and Dr. Hartwig's letter in the column headed $» H \ll$. The magnitudes are based on the BD. value, 9.5, for the star $z,+46: 3078$, and 12.8 as the assumed limit of the 6.2 -inch reflector. The light scale used was derived from all my comparisons, 156 in number, up to date, and differs somewhat from that used in A. J. 397, 434, 441 and 458 .

In regard to the differences in our estimates I may say:

1) The absorption of the blue rays by the silver film of the reflector causes red stars to appear relatively brighter than when observed with a refractor. This may account for half a magnitude, or more, of the difference.

2) The magnitudes reported by me in A. J. 397 were based on a preliminary scale, formed under somewhat unfavorable conditions; the scale finally adopted makes the stars brighter, thus reducing the difference between us.

3) I have never found the variable below the limit of the 6.2 -inch reflector, and have only twice seen it as faint as my comparison star $y$. How this can be reconciled with Dr. Hartwig's observation »für den 10-zölligen Refractor kaum sichtbark, I do not know; but as bearing on the question I might quote his statement (A.N. 3553) that RU Herculis was invisible in the 10 -inch during the summer and autumn of 1897 , while I could see it with the 6.2 -inch in July of that year (A. J. 426). In this case also the field had been measured with the micrometer, rendering the identification quite certain. Possibly the difference in atmospheric conditions enters as a large factor.

4) There still remains a wide discrepancy in the maximum of the summer or autumn of 1896 . The accompanying list of my observed magnitudes will show the steady decline which I found during August and September; but even leaving them out of account, it is difficult to explain how a false maximum at $10^{\mathrm{m}}$ could be deduced by mistaking for the variable a $\mathbf{I}^{\mathrm{m}}$ comparison star.

\begin{tabular}{|c|c|c|}
\hline 189 & & Mag. \\
\hline Nov. & & I I. I \\
\hline \multirow[t]{3}{*}{ Dec. } & 14 & I I.4 \\
\hline & 15 & I 1:5 \\
\hline & 25 & $1 \mathrm{I} \cdot 5$ \\
\hline \multicolumn{3}{|c|}{1896} \\
\hline \multirow[t]{3}{*}{ Jan. } & 6 & I I $\cdot 3$ \\
\hline & 13 & 11.4 \\
\hline & 20 & I I . 4 \\
\hline \multirow[t]{2}{*}{ Febr. } & 5 & I I.2: \\
\hline & 8 & I 1.4： \\
\hline Mar. & I & $<10.8$ \\
\hline May & 28 & I $1.3:$ \\
\hline \multirow[t]{4}{*}{ Aug. } & 3 & 9.9 \\
\hline & 4 & 10.0 \\
\hline & 10 & 10.0 \\
\hline & 17 & 10.0 \\
\hline \multirow[t]{2}{*}{ Sept. } & 7 & $\begin{array}{r}9.9 \\
10.0\end{array}$ \\
\hline & 17 & 10.2 \\
\hline
\end{tabular}

Observed Magnitudes of $7492 \mathrm{RZ}$ Cygni.

\begin{tabular}{|c|c|c|c|c|c|c|c|}
\hline \multirow{2}{*}{\multicolumn{2}{|c|}{$\begin{array}{c}\text { I } 896 \\
\text { Sept. } 22\end{array}$}} & \multirow{2}{*}{$\begin{array}{l}\text { Mag. } \\
\text { I } 0.3\end{array}$} & \multicolumn{2}{|c|}{1897} & \multirow{2}{*}{$\begin{array}{l}\text { Mag. } \\
\text { I } 1.6\end{array}$} & I 898 & \multirow{2}{*}{$\begin{array}{l}\text { Mag. } \\
\text { I I .9 }\end{array}$} \\
\hline & & & July & 24 & & June 13 & \\
\hline & 25 & 10.3 & Aug. & I I & 11.9: & 28 & 1 1.8 \\
\hline & 30 & 10.3 & Sept. & I 7 & 12.3 & July I 2 & 11.9 \\
\hline Oct. & 5 & 10.5 & & 23 & I 2.7 & 25 & 11.7 \\
\hline & 14 & 10.5 & Oct. & 14 & 12.4 & Aug. 8 & II.2 \\
\hline & 21 & 10.7 & & 25 & 12.7 & 20 & I 1.4: \\
\hline & 26 & 10.8 & Nov. & I $\mathbf{r}$ & 12.6 & Oct. 5 & I 1.2 \\
\hline Nov. & 4 & I I I I & 189 & & & Nov. I & 10.8 \\
\hline & I 2 & I 1.3 & Jan. & 17 & 10.8: & 7 & I I. I : \\
\hline & 26 & I 1.6 & & 18 & 10.9 & I 6 & I I I I \\
\hline Dec. & 23 & I I. 8 & & 26 & 10.8 & Dec. 3 & I 1.6 \\
\hline $189^{\prime}$ & & & Febr. & 15 & $10.7:$ & 13 & I 1.6 \\
\hline Jan. & 6 & 12.0 & & 23 & $10.5:$ & 30 & I $1 \cdot 3$ \\
\hline & 28 & $<\mathbf{I} 1,0$ & Mar. & 6 & 10.2: & I 899 & \\
\hline May & 28 & I 1.3 & & 23 & 10.6 & Jan. & I 1.8 : \\
\hline June & II & 11.6: & Apr. & I & I0.8 & 28 & I 1.7: \\
\hline & 25 & 11.6 & & I 5 & 10.6 & Mar. 22 & I2.1: \\
\hline July & 5 & I 1.9 & May & 7 & 10.8 & Apr. 4 & 12.7: \\
\hline
\end{tabular}


Comparison Stars.

\begin{tabular}{rrrrr} 
& \multicolumn{2}{c}{ Coor. from V. } & Mag. & H \\
& RA. & Dec. & & \\
$q$ & -13.0 & +1.4 & 11.8 & - \\
$r$ & -1.2 .1 & +3.1 & 11.1 & $b$ \\
$z$ & -9.1 & +0.1 & 9.5 & - \\
$t$ & -9.0 & -1.7 & 10.8 & $c$ \\
$x$ & -4.2 & +0.7 & 12.1 & $y$ \\
$a$ & -1.0 & -2.4 & - & -
\end{tabular}

\begin{tabular}{ccc} 
& \multicolumn{2}{c}{ Coor. from V. } \\
& RA. & Dec. \\
$b$ & -0.9 & -1.7 \\
$y$ & +2.5 & +0.6 \\
$h$ & +4.8 & -0.5 \\
$f$ & +7.2 & -1.7 \\
$m$ & +19.7 & -4.1 \\
$n$ & +32.2 & -5.6
\end{tabular}

$\begin{array}{cc}\text { Mag. } & \text { H } \\ - & - \\ 12.8 & - \\ 12.7 & - \\ 10.9 & a \\ - & e \\ - & d\end{array}$

Marengo, Illinois, 1899 April 6.

F. A. Parkhurst.

\section{Notiz betr. die totale Sonnenfinsterniss 1900 Mai 28.}

In anticipation of the total eclipse of the sun May 28, 1900, the United States Navy Department has arranged with the Secretary of the Treasury to have admitted free of duty the instruments of foreign astronomers who may come to this country to observe the eclipse.

To this end, astronomers abroad who contemplate an expedition to the United States are invited to notify the Superintendent of the Naval Observatory of the probable date of their arrival, with the name of the port at which they propose to disembark. The Navy Department will forward to the consuls of the different countries to which these observers belong, stationed at the ports in the United States at which the gentlemen shall arrive, a letter stating their purpose in travelling, which letter will be countersigned by the consul, and presented to the collector at the port as a proof of their identity. Upon this the collector will extend all proper facilities for the speedy delivery of the instruments in question, free of duty and charges.

U. S. Naval Observatory, Washington, I899 May I 7.
The Superintendent of the Observatory will be glad to hear from each of the proposed expeditions, in order that he may render such assistance as lies in his power. The path of totality extends through a thickly settled portion of the country, including some principal cities. Facilities for transportation are excellent, but it is recommended that instruments be securely packed and marked $\rightarrow$ Delicate in. struments - handle with care. The climate at that season is warm. The chances for clear weather are good.

Full information regarding routes of travel to proposed points, and other particulars, can best be obtained through consuls. Through the regular diplomatic channels, notice should be conveyed to the local authorities of the city or town selected as a post of observation.

This Observatory will issue a pamphlet of instructions, containing large scale maps showing path of totality.

C. H. Davis, Captain, U. S. N., Superintendent.

\section{Helligkeitsmessungen des Planeten Mars. \\ Von Frau F. von Prittziltz.}

In den vergangenen Monaten habe ich einige Lichtmessungen des Planeten Mars unternommen, deren Ergebniss ich mir in Folgendem zu veröffentlichen gestatte. Die Beobachtungen sind auf meinem hohen, freigelegenen Balcon angestellt, mit Hülfe eines Zöllner'schen Photometers, welches nach dem Muster des auf der Potsdamer Sternwarte be. findlichen Wanschaff'schen Instruments (siehe Müller, Photometrie der Gestirne, Seite 249) von dem Mechaniker Töpfer in Potsdam für mich angefertigt worden ist. Der Apparat ist in etwas grösseren Verhältnissen ausgeführt als der Potsdamer und unterscheidet sich von demselben dadurch, dass das Colorimeter in Wegfall gekommen ist, und an Stelle der dadurch entbehrlich gewordenen Quarzplatte und des einen Nicolprismas ein blaues Glas eingesetzt ist, welches die röthliche Farbe des künstlichen Sternes in eine weissliche verwandelt. Die Lampe ist, ausser durch einen doppelten Blechcylinder, noch durch einen grösseren Kasten gegen den Luftzug so vollkommen geschützt, dass sie auch bei stärkerem Winde in Freien ruhig und gleichmässig brennt. Von den drei zum Photometer gehörigen Objectiven mit Oeffnungen von 91,40 und $28 \mathrm{~mm}$, ist $z u$ den Marsbeobachtungen das kleinste benutzt worden, welches ron dem Planeten ein punktartiges Bild liefert; um die grosse Helligkeit des Mars zu mildern, ist bei allen Messungen noch ein neutral gefärbtes Glas vor das Objectiv gesetzt worden.

Die Beobachtungen wurden in der Weise ausgeführt, dass Anfangs zwei Einstellungen des zur Vergleichung ausgewählten Fixsternes gemacht wurden, dann vier Einstellungen des Mars und zuletzt abermals zwei Einstellungen des Ver. gleichsternes. Die Grössen der Vergleichsterne sind der Planetenarbeit von Prof. Müller (Publ. des Astrophys. Observ. zu Potsdam, Band 8, Seite 235) entnommen.

In der unten folgenden Tabelle ist in Spalte 2 die Zeit der Beobachtung (etwa bis auf zwei Minuten genau) angegęben. Die Spalten 4 und 5 enthalten die Mittel der Ablesungen für Planet und Vergleichstern, die beiden folgenden die Zenithdistanzen, welche für die angegebene Beobachtungszeit aus einer, von mir berechneten, Tafel entnommen wurden. Mit Hülfe dieser $Z$ und $Z^{\prime}$ sind die $\log \sin ^{2} \mathcal{F}$ und $\log \sin ^{2} \mathcal{F}^{\prime}$ für Extinction verbessert und 